\title{
Influence of environmental conditions on the regenerative capacity and the survivability of Elodea nuttallii fragments
}

\author{
Markus HOFFMANN, ${ }^{*}$ Uta READER, Arnulf MELZER \\ Chair of Aquatic Systems Biology, Limnologische Station Iffeldorf, Technische Universität München, Hofmark 3, 82393 Iffeldorf, \\ Germany \\ *Corresponding author: Markus.Hoffmann@tum.de
}

\begin{abstract}
The presented study was conducted to determine which environmental factors and conditions can affect the regenerative capacity and survivability of Elodea nuttallii and therefore the efficiency of mechanical management methods like cutting and harvesting. The influence of water temperature, light intensity and nutrient concentration in the sediment on the survivability and regenerative capacity of the invasive species E. nuttallii was determined in three laboratory and one field experiments. E. nuttallii fragments with one to four nodes were stored in aquaria under constant temperature and/or light conditions. To examine the influence of water temperature, four aquaria were kept at a constant water temperature of either $15^{\circ} \mathrm{C}$ or $20^{\circ} \mathrm{C}$. The influence of light intensity was studied by shading the aquaria with different types of mesh. The fragments were stored at constant light intensities of 215, 161, 86 and 31 umol photons $m^{-2} s^{-1}$. Fragments in aquaria filled with sediment with $20 \mu \mathrm{g} \mathrm{P}_{2} \mathrm{O}_{5}-\mathrm{P} \mathrm{g} \mathrm{g}^{-1}$ soil, $150 \mu \mathrm{g} \mathrm{P}_{2} \mathrm{O}_{5}-\mathrm{P} \mathrm{g} \mathrm{g}^{-1}$ soil or without sediment were studied to determine the influence of the sediment. The results of the laboratory experiments showed how the mechanical management methods are most efficient during periods with low water temperatures, high turbidity or low global irradiation and nutrient poor waters. The field experiment was designed to study the influence of the nutrient compositions in the sediment on the growth and regenerative capacity of rooted $\mathrm{E}$. nuttallii. E. nuttallii fragments were planted in compartments treated with $\mathrm{PO}_{4}{ }^{3-}$ and/or $\mathrm{NH}_{4}{ }^{+}$-fertiliser and were trimmed after six weeks. The experiment revealed that the growth before a harvest and the growth after a harvest (regenerative capacity) differ significantly, depending on the nutrient composition in the substrate. An increase of the $\mathrm{PO}_{4}^{3-}$ concentration in the sediment, for example, reduced the growth of $\mathrm{E}$. nuttallii before the harvest, but increased the growth after the harvest. A treatment with $\mathrm{PO}_{4}^{3-}$ and $\mathrm{NH}_{4}^{+}-$ fertiliser had an opposite effect on growth and regenerative capacity. The study proved that the environmental conditions have a significant influence on the efficiency of mechanical management methods.
\end{abstract}

Key words: Sediment, light, water temperature, neophyte, nutrient concentration, invasive, fertiliser.

Received: January 2014. Accepted: June 2014.

\section{INTRODUCTION}

Elodea nuttallii (Planch.) H. St. John is one of the invasive neophytes of the genus Elodea, which have spread across Europe during the last century (Kowarik, 2003; Hussner et al., 2010; Hussner, 2012). E. nuttallii was first introduced to Europe in 1936, almost 100 years after the closely related Elodea canadensis Michx. had reached Europe (Simpson, 1984; Kowarik, 2003; Hussner, 2012). Although $E$. nuttallii was introduced later than $E$. canadensis, it has replaced E. canadensis in many European lakes and rivers (Simpson, 1990; Barrat-Segretain, 2001). The excessive growth of E. nuttallii often has a negative influence on the economic interests of fishery and tourism in lakes (Podraza et al., 2008) and can affect the biodiversity of lakes by out-competing the less robust native species and by releasing allelochemicals into the water (Barrat-Segretain, 2005; Kelly and Hawes, 2005; Erhard and Gross, 2006; Erhard et al., 2007).

The management of invasive macrophytes like $E$. nuttallii can be difficult and it is often limited to mechanical control methods, because chemical and biological management methods are commonly restricted or prohibited, for example by European and national water regulation laws. The methods most commonly applied in European lakes are cutting and harvesting of macrophytes. These methods, however, are often costly and non-specific (Pieterse and Murphy, 1990). Usually, this leads to shortterm effects only or, as in the case of E. nuttallii, can even cause the unintentional spread of fragments (Nino et al., 2005). E. nuttallii, similar to E. canadensis, is able to regenerate from small fragments (Barrat-Segretain and Bornette, 2000; Barrat-Segretain et al., 2002) and has the ability to adapt to a large range of environmental conditions, for example low light conditions or low water temperatures (Barrat-Segretain and Bornette, 2000; Jones et al., 2000; Tremp, 2001; Barrat-Segretain et al., 2002; Barrat-Segretain, 2005; Herault et al., 2008; Angelstein and Schubert, 2009; Mazej, 2014). Therefore, the fragments created through cutting enable $E$. nuttallii to colonise new locations and spread over a large area. The cutting of $E$. nuttalii populations is, as a result of this, commonly com- 
bined with a harvest to remove the fragments from the lake (Pieterse and Murphy, 1990). However, small fragments often remain in the lakes and in some cases the mechanical strain of the harvest can increase the amount of small fragments (M. Hoffmann, personal observation).

Some studies showed that $E$. nuttallii prefers specific environmental conditions, for example low light intensities or warm water temperatures (Kunii, 1982; Kunii, 1984a; Jones et al., 2000; Angelstein and Schubert, 2009; Mazej, 2014). Those studies also indicated that environmental factors can affect $E$. nuttallii fragments by accelerating or inhibiting their growth. Consequently, some environmental conditions might increase the efficiency of mechanical management methods, especially the cutting and harvesting, by reducing the regenerative capacity and survivability of fragments of $E$. nuttallii. The presented study was conducted to investigate this possibility, more precisely to determine which environmental factors and environmental conditions can affect the regenerative capacity and survivability of fragments and therefore might affect the efficiency of mechanical control methods.

\section{METHODS}

\section{Experimental materials}

The plant material used during the experiments was collected from a mesotrophic water basin (Lake Starn-

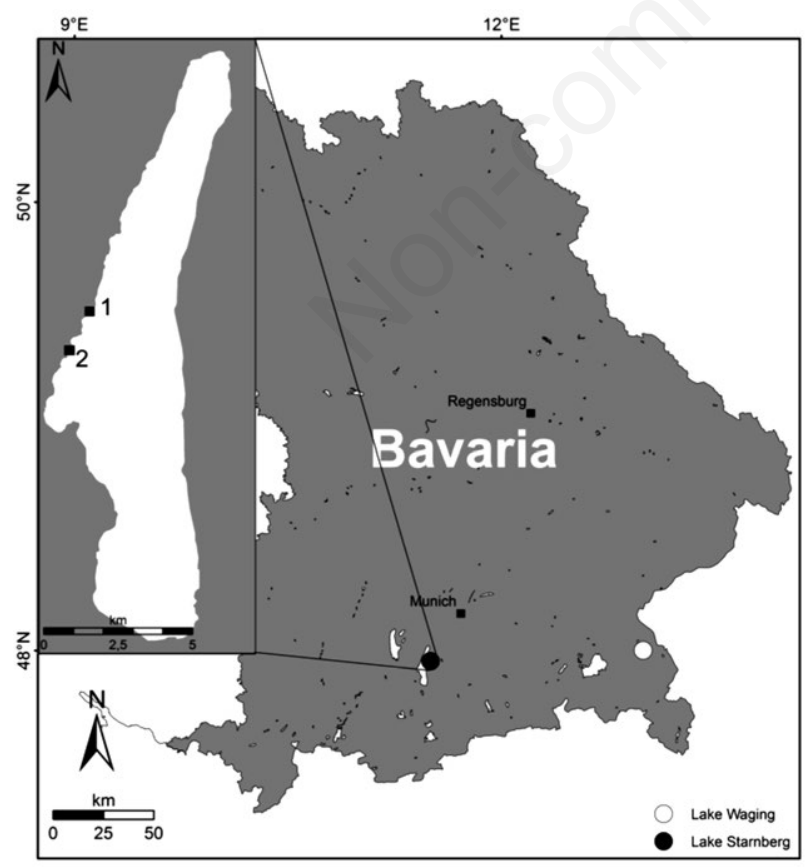

Fig. 1. Sampling and experimental sites in South Germany (Bavaria). Lake Starnberg: 1) Plant material and sediment sampling site, location of field experiment; 2) Lake water sampling site. berg) near the city of Munich (Fig. 1; Tab. 1: Water Lake) in South Germany. Similarly, the water as well as the sediment were collected from a location in the Lake Starnberg with a large population of E. nuttallii (Fig. 1).

\section{Laboratory experiments}

\section{Experimental setup}

The influence of water temperature, light intensity and sediment conditions on the growth and survivability of small E. nuttallii fragments was studied in three growth experiments under laboratory conditions. All experiments were conducted in $40 \mathrm{~L}$ aquaria fitted with pumps and filled with lake water and a $5 \mathrm{~cm}$ layer of lake sediment (Tab. 1: Sediment 1). Based on experiences made during previous experiments, the water in the aquaria was partially replaced every two to three weeks to prevent changes in the water quality. Prior to the experiments, E. nuttallii was cultivated under laboratory conditions for at least eight weeks. The plants were stored at a water temperature of $15^{\circ} \mathrm{C}$, a 12 hour day-night rhythm and a light intensity of $215 \mu \mathrm{mol}$ photons $\mathrm{m}^{-2} \mathrm{~s}^{-1}$ (measured at the water surface). After then, the aquaria were sub-divided into 24 compartments with acrylic glass to separate the plant fragments, thus simplifying the identification and measuring of the fragments. However, the sub-divisions allowed free water exchange within the aquaria. The lake water and the environmental conditions used in the experiments were the same used for cultivating E. nuttallii (Tab. 1: Water - Aquaria).

Based on observations made by the authors during various management campaigns and field experiments, four different sizes of small fragments were chosen: $E$. nuttallii fragments with a length between one and four nodes (including the apex) were used during the experiments. Only one fragment was taken from each plant and placed in one of the 24 compartments in the sub-divided

Tab. 1. Nutrient concentration in the sediments and water used in the experiments.

\begin{tabular}{|c|c|c|c|c|c|}
\hline \multicolumn{2}{|c|}{ Sediment } & $\begin{array}{c}\mathrm{NO}_{3}^{-} \\
\left(\mu \mathrm{gg} \mathrm{g}^{-1} \text { soil) }\right.\end{array}$ & $\begin{array}{c}\mathrm{NH}_{4}^{+} \\
\left(\mu \mathrm{g} \mathrm{g}^{-1} \text { soil }\right)\end{array}$ & $\begin{array}{c}\mathrm{P}_{2} \mathrm{O}_{5}-\mathrm{P} \\
\left(\mathrm{\mu g} \mathrm{g}^{-1} \text { soil }\right)\end{array}$ & $\begin{array}{r}\mathrm{P}_{2} \mathrm{O}_{5}-\mathrm{P}_{\text {tot }} \\
\left(\mu \mathrm{\mu g} \mathrm{g} \mathrm{g}^{-1} \text { soil }\right.\end{array}$ \\
\hline \multirow{2}{*}{\multicolumn{2}{|c|}{$\begin{array}{l}\text { Sediment } 1 \\
\text { Sediment } 2\end{array}$}} & $<$ d.1. & 5.0 & 20 & 500 \\
\hline & & $<$ d.1. & 352 & 150 & 500 \\
\hline \multicolumn{2}{|c|}{ Interstitial water } & $\begin{array}{l}\mathrm{NO}_{3}-\mathrm{N} \\
\left(\mu \mathrm{L}^{-1}\right)\end{array}$ & $\begin{array}{c}\mathrm{NH}_{4}-\mathrm{N} \\
\left(\mu \mathrm{g} \mathrm{L}^{-1}\right)\end{array}$ & $\begin{array}{c}\mathrm{PO}_{4}-\mathrm{P} \\
\left(\mu \mathrm{g} \mathrm{L}^{-1}\right)\end{array}$ & $\%$ soil \\
\hline \multirow{2}{*}{\multicolumn{2}{|c|}{$\begin{array}{l}\text { Sediment } 1 \\
\text { Sediment } 2\end{array}$}} & $<10$ & 555 & 16 & 37.7 \\
\hline & & 700 & 741 & 111 & 50.8 \\
\hline Water & $\mathrm{pH}$ & $\begin{array}{l}\mathrm{NO}_{3}-\mathrm{N} \\
\left(\mu \mathrm{LL}^{-1}\right)\end{array}$ & $\begin{array}{l}\mathrm{NH}_{4}-\mathbf{N} \\
\left(\mu g \mathrm{~L}^{-1}\right)\end{array}$ & $\begin{array}{l}\mathrm{PO}_{4}-\mathrm{P} \\
\left(\mu g \mathrm{~L}^{-1}\right)\end{array}$ & $\begin{array}{l}\mathrm{PO}_{4}-\mathrm{P}_{\text {tot }} \\
\left(\mathrm{\mu g} \mathrm{L}^{-1}\right)\end{array}$ \\
\hline Aquaria & 8.5 & 300 & 10 & $<10$ & 18 \\
\hline Lake & 8.5 & 300 & 10 & $<10$ & 18 \\
\hline
\end{tabular}

d.l., detection limit. ${ }^{*}$ Share of interstitial water in the sediment. 
aquaria. After seven days of acclimation the length of the fragments was measured at least once a week for a total of 56 days (eight weeks). The length of the plants was determined by analysing photos of the fragments with the measurement software Kappa ImageBase (KIB). This method was chosen to avoid unnecessary disturbances during the experiments. At the end of the experiments all plants were harvested and the final length, as well as the dry weight, of the plants was determined.

Based on the measurements of the plants, the mean length increment rates (RGR-L) were calculated as [ $\ln$ (final length) $-\ln$ (initial length)] / days. Additionally, the relative growth rate $(\mathrm{RGR})=[\ln$ (final dry weight) $\ln$ (initial dry weight)] / days was calculated for the dry weight of the plants. The standard error of the mean (SEM) was computed for mean RGR-L and RGR.

\section{Temperature experiment}

The temperature experiment was designed to determine if the water temperature during mechanical management can affect the survival and the regenerative capacity of small E. nuttallii fragments. E. nuttallii fragments with one to four nodes were placed in four aquaria filled with the same sediment (Tab. 1: Sediment 1) and water (Tab. 1) used in the aquaculture and a 12 hour day-night rhythm with a constant light intensity of $215 \mu \mathrm{mol}$ photons $\mathrm{m}^{-2} \mathrm{~s}^{-1}$. Each aquarium contained 24 fragments (six of each length) which were randomly placed in one of the compartments. Two of the aquaria were stored at a water temperature of $15^{\circ} \mathrm{C}$ (cold water condition), the remaining two aquaria were stored at $20^{\circ} \mathrm{C}$ (warm water condition).

\section{Light experiment}

The aim of the light experiments was to study the effect of reduced light intensities on the survival and regenerative capacity of E. nuttallii. The experimental setup consisted of one control ( $100 \%$ light intensity $=215 \mu \mathrm{mol}$ photons $\mathrm{m}^{-2} \mathrm{~s}^{-1}$ ) and three variations in light conditions ( $75 \%=161 \mu \mathrm{mol}$ photons $\mathrm{m}^{-2} \mathrm{~s}^{-1}, 40 \%=86 \mu \mathrm{mol}$ photons $\mathrm{m}^{-2} \mathrm{~s}^{-1}$ and $15 \%=32 \mu \mathrm{mol}$ photons $\mathrm{m}^{-2} \mathrm{~s}^{-1}$ ). The different light intensities were created by shading the aquaria with multiple layers of metal mesh. A total of eight aquaria, with a setup identical to the one used in the temperature experiment, were exposed to the light conditions (two aquaria per light intensity). The aquaria were stored at a temperature of $15^{\circ} \mathrm{C}$.

\section{Sediment experiment}

The third experiment conducted under laboratory conditions focused on the influence of the sediment on the survival and the regenerative capacity of E. nuttallii fragments. Three different setups were used during the experiment: i) two aquaria were filled only with lake water
(Tab. 1: Water - Aquaria) and remained without sediment; ii) two aquaria were filled with a $5 \mathrm{~cm}$ layer of the same sediment (Tab. 1: Sediment 1) used during the previous experiments; iii) two aquaria were filled with sediment collected from a location at the northern lakeshore of Lake Waging (Fig. 1) dominated by Najas marina ssp. intermedia L. (Tab. 1: Sediment 2), which contained considerably higher nutrient concentrations than the sediment used during the previous experiments.

Because of the high mortalities of the fragments with one node during the previous experiments, only fragments with two, three or four nodes were used in the experimental setup. Additionally, the amount of fragments with the same length was increased to eight per aquarium. The aquaria were stored at $15^{\circ} \mathrm{C}$ and a 12 hour day-night rhythm with a constant light intensity of $215 \mu \mathrm{mol}$ photons $\mathrm{m}^{-2} \mathrm{~s}^{-1}$.

\section{Field experiment}

In addition to the laboratory experiments, a field study was conducted in the Lake Starnberg (Fig. 1). The aim of the experiment was to determine whether certain nutrients or combinations of nutrients in the sediment, can affect the regenerative capacity of $E$. nuttallii and therefore the success of mechanical management methods under natural conditions. The experimental setup consisted of eight aluminium trays, measuring $60 \times 20 \times 15 \mathrm{~cm}$ (width $\mathrm{x}$ high $\mathrm{x}$ depth) each with three pods $(20 \times 20 \times 15 \mathrm{~cm})$ and a volume of six L. The pods contained four L sediment collected from a location dominated by E. nuttallii (Tab. 1: Sediment 1; Fig. 1) and were planted with four E. nuttallii sprouts, each with an initial length of eight $\mathrm{cm}$.

Apart from the control, the pods were treated with $\mathrm{NH}_{4}{ }^{+}$-fertiliser, $\mathrm{PO}_{4}{ }^{3-}$ fertiliser or a combination of both. The concentration of $\mathrm{NH}_{4}{ }^{+}$and / or $\mathrm{PO}_{4}{ }^{3-}$, was increased in each compartment by $200 \mu \mathrm{g}$ per L interstitial water by adding the corresponding amount of $\mathrm{NH}_{4} \mathrm{Cl}$ and $\mathrm{Na}_{2} \mathrm{HPO}_{4}$ to the sediment. The upper surface of the compartments was covered with a $1 \mathrm{~cm}$ layer of nutrient free sand to avoid a direct exchange with the lake water. The controls, as well as the treated pods, were replicated six times. The aluminium trays were placed randomly on a platform at a depth of three $\mathrm{m}$. The trays were deployed at the beginning of June 2010 and after one week of acclimation the total shoot length per pod was measured weekly. Seven weeks after the start of the experiment all plants were trimmed to simulate a harvest. The cut plant material was collected and the fresh weight as well as the dry weight of the material was determined. At the end of the experiment the remaining plant material was harvested and weighed.

\section{Chemical analysis}

The concentration of soluble reactive phosphorus (SRP), total phosphorus (total P), ammonium $\left(\mathrm{NH}_{4}^{+}\right)$and 
nitrate $\left(\mathrm{NO}_{3}^{-}\right)$in the water was determined using Phosphate test P6/25 (0.01-5.00 $\left.\mathrm{mg} \mathrm{L}^{-1} \mathrm{PO}_{4}{ }^{3-}\right), 14739$ (0.01-2.00 mg $\left.\mathrm{L}^{-1} \mathrm{NH}_{4}^{+}\right)$and $14556\left(0.1-3.00 \mathrm{mg} \mathrm{L}^{-1} \mathrm{NO}_{3}^{-}\right)$from WTW (Wissenschaftlich-Technische-Werkstätten, Weilheim, Germany) and the photometer PhotoLab S12 (WTW). The analysis of the homogenised sediment samples was carried out by AGROLAB Labor GmbH. Extractable phosphorus and total phosphorus were measured as $\mathrm{P}_{2} \mathrm{O}_{5}-\mathrm{P}$ using the acetate lactate method for extractable phosphorus and inductively coupled plasma optical emission spectrometry (DIN ISO EN 11885) for total phosphorus. Nitrate was measured by flow analysis (DIN ISO EN 13395-D28) and ammonia according to DIN ISO EN 38406-E5.

\section{Statistical analysis}

Statistical analysis was conducted using the free statistic software R (ver. 2.10.1, The R Foundation for Statistical Computing). Data from the measurements were analysed with two-way analysis of variance (two-way ANOVA) and LSD (Least Significant Difference) posthoc tests with Bonferroni correction to identify significant differences between groups. The interaction between the environmental conditions and the growth of $E$. nuttallii was analysed with a linear mixed effect model (R-package nlme). The linear mixed effect model was fitted by restricted maximum likelihood (REML) and contained a random intercept mixed effect with the subject (plant) as random. The length as function of the time and the environmental conditions and/or the amount of nodes was assumed as fixed effect for the linear mixed model.

\section{RESULTS}

\section{Laboratory experiments}

\section{Temperature experiment}

The mortality of the fragments decreased with a higher amount of initial nodes (Tab. 2). In the aquaria with a water temperature of $20^{\circ} \mathrm{C}$, more than $90 \%$ of the fragments with one initial node died during the experiment. The one node fragments in the $15^{\circ} \mathrm{C}$ aquaria showed a higher survival rate, but still only $33 \%$ of the fragments survived. In the aquaria with $20^{\circ} \mathrm{C} 66 \%$ of the fragments with an initial length of two nodes died. The survival rate of the fragments was only slightly higher in water with $15^{\circ} \mathrm{C}$. The fragments with an initial size of three or four nodes showed high survival rates and no differences in water with $15^{\circ} \mathrm{C}$ or $20^{\circ} \mathrm{C}$. The temperature experiment revealed a significant influence of the water temperature on the growth of E. nuttallii. Fragments with two or three initial nodes grew more than two times faster and developed between $25 \%$ and $30 \%$ more biomass in aquaria with a water temperature of $20^{\circ} \mathrm{C}$ than fragments in the $15^{\circ} \mathrm{C}$ aquaria. In contrast to this, neither the longitudinal growth nor the biomass growth of the fragments with four initial nodes was affected by the water temperature.

\section{Light experiment}

The light experiment revealed considerable differences in the mortality of the fragments depending on light intensity and the amount of initial nodes. Similar to the temperature experiment, the larger fragments showed an overall higher survivability compared to the smaller fragments (Tab. 3).

Between $33 \%$ and $66 \%$ of the fragments with one initial node died during the experiment. The aquaria with 86 and $32 \mu \mathrm{mol}$ photons $\mathrm{m}^{-2} \mathrm{~s}^{-1}$ light intensity showed the highest mortality with $66 \%$. All fragments with three or four nodes, grown in aquaria with 215,161 or 86 $\mu \mathrm{mol}$ photons $\mathrm{m}^{-2} \mathrm{~s}^{-1}$ light intensity, survived until the end of the experiment. The overall average mortality was $42 \%$ highest in the aquaria with $32 \mu \mathrm{mol}$ photons $\mathrm{m}^{-2} \mathrm{~s}$ ${ }^{1}$ compared to $29 \%$ at $215 \mu \mathrm{mol}$ photons $\mathrm{m}^{-2} \mathrm{~s}^{-1}, 17 \%$ at $161 \mu \mathrm{mol}$ photons $\mathrm{m}^{-2} \mathrm{~s}^{-1}$ and $21 \%$ at $86 \mu \mathrm{mol}$ photons

Tab. 2. Mean relative growth rates and mortalities at the end of the temperature experiment. Data is shown with standard error of the mean.

\begin{tabular}{|c|c|c|c|c|}
\hline Water temperature & $\begin{array}{c}1 \text { node } \\
\left(\mathrm{RGR}-\mathrm{L} \mathrm{d}^{-1}\right)\end{array}$ & $\begin{array}{c}2 \text { nodes } \\
\left(\mathrm{RGR}-\mathrm{L} \mathrm{d}^{-1}\right)\end{array}$ & $\begin{array}{c}3 \text { nodes } \\
\left(\mathrm{RGR}-\mathrm{L} \mathrm{d}^{-1}\right)\end{array}$ & $\begin{array}{c}4 \text { nodes } \\
\left(\text { RGR-L d } d^{-1}\right)\end{array}$ \\
\hline $\begin{array}{l}15^{\circ} \mathrm{C} \\
20^{\circ} \mathrm{C}\end{array}$ & $\begin{array}{c}0.027(0.015) \\
0.084(0)\end{array}$ & $\begin{array}{l}0.024(0.018)^{\mathrm{a}} \\
0.053(0.024)^{\mathrm{b}}\end{array}$ & $\begin{array}{l}0.030(0.012)^{\mathrm{a}} \\
0.070(0.018)^{\mathrm{b}}\end{array}$ & $\begin{array}{l}0.031(0.028)^{\mathrm{a}} \\
0.031(0.024)^{\mathrm{a}}\end{array}$ \\
\hline Water temperature & $\begin{array}{c}1 \text { node } \\
\left(\mathrm{RGR} \mathrm{d}^{-1}\right)\end{array}$ & $\begin{array}{c}2 \text { nodes } \\
\left(\mathrm{RGR} \mathrm{d}^{-1}\right)\end{array}$ & $\begin{array}{c}3 \text { nodes } \\
\left(\mathrm{RGR} \mathrm{d}^{-1}\right)\end{array}$ & $\begin{array}{c}4 \text { nodes } \\
\left(\operatorname{RGR~d}^{-1}\right)\end{array}$ \\
\hline $\begin{array}{l}15^{\circ} \mathrm{C} \\
20^{\circ} \mathrm{C}\end{array}$ & $\begin{array}{c}0.103(0.009) \\
0.121(0)\end{array}$ & $\begin{array}{l}0.101(0.002)^{\mathrm{a}} \\
0.128(0.006)^{\mathrm{b}}\end{array}$ & $\begin{array}{l}0.110(0.016)^{\mathrm{a}} \\
0.147(0.008)^{\mathrm{b}}\end{array}$ & $\begin{array}{l}0.136(0.003)^{\mathrm{a}} \\
0.133(0.008)^{\mathrm{a}}\end{array}$ \\
\hline Water temperature & $\begin{array}{c}\text { node } \\
\text { Mortality }(\%)\end{array}$ & $\begin{array}{c}2 \text { nodes } \\
\text { Mortality (\%) }\end{array}$ & $\begin{array}{c}\text { nodes } \\
\text { Mortality }(\%)\end{array}$ & $\begin{array}{c}4 \text { nodes } \\
\text { Mortality (\%) }\end{array}$ \\
\hline $\begin{array}{l}15^{\circ} \mathrm{C} \\
20^{\circ} \mathrm{C}\end{array}$ & $\begin{array}{l}66.6 \\
91.6\end{array}$ & $\begin{array}{l}58.3 \\
66.6\end{array}$ & $\begin{array}{l}33.3 \\
33.3\end{array}$ & $\begin{array}{l}16.6 \\
16.6\end{array}$ \\
\hline
\end{tabular}

$R G R-L$, relative longitudinal growth rate; $R G R$, relative biomass growth rate. ${ }^{a, b}$ Different superscripts in the same column indicate significant differences $(P<0.05)$. The high mortality of the fragments with one node did not allow the statistical analysis of the respective growth rates. 
$\mathrm{m}^{-2} \mathrm{~s}^{-1}$. The fragments with one or two initial nodes showed only marginal longitudinal growth and biomass growth in the aquaria without shading $(215 \mu \mathrm{mol}$ photons $\mathrm{m}^{-2} \mathrm{~s}^{-1}$ ). The growth rates, especially the biomass growth rates, of the fragments with one or two nodes, increased with shading. The small fragments showed the highest biomass growth rates in the aquaria with only 32 $\mu$ mol photons $\mathrm{m}^{-2} \mathrm{~s}^{-1}$. In contrast, the growth rate of fragments with an initial size of three or four nodes decreased with shading. Plants in aquaria with $32 \mu \mathrm{mol}$ photons $\mathrm{m}^{-2} \mathrm{~s}^{-1}$ showed less than $20 \%$ longitudinal growth and only $70 \%$ to $90 \%$ biomass growth compared to the aquaria with $215 \mu \mathrm{mol}$ photons $\mathrm{m}^{-2} \mathrm{~s}^{-1}$.

The linear mixed effect models, computed for the fragment with three or four initial nodes, revealed a highly significant influence of the light intensity on the longitudinal growth during the experiment (time $\mathrm{x}$ light intensity $\mathrm{P}<0.05$ ). A more detailed analysis showed a significant influence of the light intensity on the longitudinal growth of the $E$. nuttalli fragments with four nodes in the aquaria with $32 \mu \mathrm{mol}$ photons $\mathrm{m}^{-2} \mathrm{~s}^{-1}$ (time $\mathrm{x}$ light intensity $\mathrm{P}<0.05$ ), $86 \mu \mathrm{mol}$ photons $\mathrm{m}^{-2} \mathrm{~s}^{-1}$ (time $\mathrm{x}$ light intensity $\mathrm{P}<0.05$ ) and $161 \mu \mathrm{mol}$ photons $\mathrm{m}^{-2} \mathrm{~s}^{-1}$ (time $\mathrm{x}$ light intensity $\mathrm{P}=0.05$ ). The data of the fragments with three initial nodes showed a highly significant influence of the light intensity on the length in the aquaria with 32, 86 and 161 $\mu \mathrm{mol}$ photons $\mathrm{m}^{-2} \mathrm{~s}^{-1}$ (time $\mathrm{x}$ light intensity $\mathrm{P}<0.05$ ). The high mortality of the fragments with one or two nodes prohibited the analysis of the growth with linear mixed effect models.

\section{Sediment experiment}

The third experiment conducted under laboratory conditions revealed that the sediment can affect the survivability of $E$. nuttallii fragments. Plants in aquaria without sediments showed a mortality of $25 \%$ regardless of the amount of initial nodes. Fragments in aquaria with sediment, on the other hand, showed mortalities of only $13 \%$ or less (Tab. 4). The nutrient concentration had no verifiable influence on the mortality of the fragments. However, the nutrient concentration of the sediment affected the growth of the plants. Fragments in aquaria filled with Sediment 2, which contained a larger amount of plant available phosphorus compared to Sediment 1 (Tab. 1), showed significantly higher growth rates than plants in aquaria filled with Sediment 1 or without sediment (Tab. 4).

\section{Field experiment}

In the period before the cutting and harvesting of the plants, E. nuttallii growing on sediment treated only with a $\mathrm{PO}_{4}{ }^{3-}$ fertiliser showed considerably lower longitudinal growth rates compared to the E. nuttallii plants growing on non-fertilised sediment (control) or on sediment treated with a $\mathrm{NH}_{4}{ }^{+}$and $\mathrm{PO}_{4}{ }^{3-}$ or $\mathrm{NH}_{4}{ }^{+}$fertiliser (Fig. 2, Tab. 5, $\mathrm{P}<0.05$ ). The longitudinal growth rates of $E$. nuttallii after the harvest, on the other hand, were considerably higher on $\mathrm{PO}_{4}{ }^{3-}$ fertilised sediment than the growth rates of the

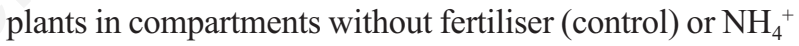
and $\mathrm{PO}_{4}{ }^{3-}$ or $\mathrm{NH}_{4}{ }^{+}$fertilisers (Fig. 2, Tab. 5, $\mathrm{P}<0.05$ ).

The compartments treated with a combination of $\mathrm{NH}_{4}^{+}$

Tab. 3. Mean relative growth rates and mortalities at the end of the light experiment. Data is shown with standard error of the mean.

\begin{tabular}{|c|c|c|c|c|}
\hline $\begin{array}{l}\text { Light intensity } \\
\text { (pmol photons } \mathrm{m}^{-2} \mathrm{~s}^{-1} \text { ) }\end{array}$ & $\begin{array}{l}1 \text { node } \\
\left(\text { RGR-L d }{ }^{-1}\right)\end{array}$ & $\begin{array}{c}2 \text { nodes } \\
(\text { RGR-L d }\end{array}$ & $\begin{array}{c}3 \text { nodes } \\
\left(\text { RGR-L d } d^{-1}\right)\end{array}$ & $\begin{array}{l}4 \text { nodes } \\
\left(\text { RGR-L d } d^{-1}\right)\end{array}$ \\
\hline $\begin{array}{l}100 \%(215) \\
75 \%(161) \\
40 \%(86) \\
15 \%(32)\end{array}$ & $\begin{array}{l}0.001(0.001)^{\mathrm{a}} \\
0.004(0.006)^{\mathrm{a}} \\
0.002(0.001)^{\mathrm{a}} \\
0.009(0.005)^{\mathrm{b}}\end{array}$ & $\begin{array}{l}0.001(0.005)^{\mathrm{a}} \\
0.006(0.008)^{\mathrm{b}} \\
0.009(0.009)^{\mathrm{b}} \\
0.008(0.005)^{\mathrm{b}}\end{array}$ & $\begin{array}{l}0.024(0.007)^{\mathrm{a}} \\
0.026(0.006)^{\mathrm{a}} \\
0.016(0.003)^{\mathrm{b}} \\
0.004(0.005)^{\mathrm{c}}\end{array}$ & $\begin{array}{l}0.030(0.002)^{\mathrm{a}} \\
0.036(0.010)^{\mathrm{a}} \\
0.017(0.003)^{\mathrm{b}} \\
0.004(0.003)^{\mathrm{c}}\end{array}$ \\
\hline $\begin{array}{l}\text { Light intensity } \\
\text { (umol photons } \mathrm{m}^{-2} \mathrm{~s}^{-1} \text { ) }\end{array}$ & $\begin{array}{c}1 \text { node } \\
\left(\mathrm{RGR} \mathrm{d}^{-1}\right)\end{array}$ & $\begin{array}{c}2 \text { nodes } \\
\left(\operatorname{RGR~d}^{-1}\right)\end{array}$ & $\begin{array}{c}3 \text { nodes } \\
\left(\operatorname{RGR} \mathrm{d}^{-1}\right)\end{array}$ & $\begin{array}{c}4 \text { nodes } \\
\left(\mathrm{RGR} \mathrm{d}^{-1}\right)\end{array}$ \\
\hline $\begin{array}{l}100 \%(215) \\
75 \%(161) \\
40 \%(86) \\
15 \%(32)\end{array}$ & $\begin{array}{c}<0.001(0) \\
0.089(0.001)^{\mathrm{a}} \\
0.094(0.002)^{\mathrm{a}} \\
0.104(0.006)^{\mathrm{b}}\end{array}$ & $\begin{array}{c}<0.001(0) \\
0.099(0.006)^{\mathrm{a}} \\
0.092(0.006)^{\mathrm{a}} \\
0.113(0.008)^{\mathrm{b}}\end{array}$ & $\begin{array}{l}0.123(0.010)^{\mathrm{a}} \\
0.113(0.004)^{\mathrm{b}} \\
0.110(0.004)^{\mathrm{b}} \\
0.112(0.008)^{\mathrm{b}}\end{array}$ & $\begin{array}{l}0.135(0.015)^{\mathrm{a}} \\
0.132(0.006)^{\mathrm{a}} \\
0.112(0.002)^{\mathrm{b}} \\
0.094(0.004)^{\mathrm{c}}\end{array}$ \\
\hline $\begin{array}{l}\text { Light intensity } \\
\text { (pmol photons } \mathrm{m}^{-2} \mathrm{~s}^{-1} \text { ) }\end{array}$ & $\begin{array}{c}1 \text { node } \\
\text { Mortality }(\%)\end{array}$ & $\begin{array}{c}2 \text { nodes } \\
\text { Mortality (\%) }\end{array}$ & $\begin{array}{c}3 \text { nodes } \\
\text { Mortality (\%) }\end{array}$ & $\begin{array}{c}4 \text { nodes } \\
\text { Mortality (\%) }\end{array}$ \\
\hline $\begin{array}{l}100 \%(215) \\
75 \%(161) \\
40 \%(86) \\
15 \%(32)\end{array}$ & $\begin{array}{c}50 \\
33.3 \\
66.6 \\
66.6\end{array}$ & $\begin{array}{l}66.6 \\
33.3 \\
16.6 \\
33.3\end{array}$ & $\begin{array}{c}0 \\
0 \\
0 \\
50\end{array}$ & $\begin{array}{c}0 \\
0 \\
0 \\
16.6\end{array}$ \\
\hline
\end{tabular}

$R G R-L$, relative longitudinal growth rate; $R G R$, relative biomass growth rate. ${ }^{a, b, c}$ Different superscripts in the same column indicate significant differences $(P<0.05)$. 
and $\mathrm{PO}_{4}{ }^{3-}$, as well as the compartments treated only with $\mathrm{NH}_{4}{ }^{+}$, developed considerably more biomass (fresh and dry weight) than the control compartments (fresh weight: $\mathrm{P}<0.05$, dry weight: $\mathrm{P}<0.05$ ) or the compartments with increased $\mathrm{PO}_{4}{ }^{3-}$ concentrations in the period before the harvest (fresh weight $\mathrm{P}<0.05$, dry weight: $\mathrm{P}<0.05$ ) (Fig. 1, Tab. 5). In contrast to this, the E. nuttallii plants in the $\mathrm{PO}_{4}{ }^{3-}$ treated compartments developed more biomass after the harvest than the plants in the control compartments (fresh weight: $\mathrm{P}<0.05$, dry weight: $\mathrm{P}<0.05$ ) or the compartments treated with a combination of $\mathrm{NH}_{4}{ }^{+}$and $\mathrm{PO}_{4}{ }^{3-}$ (fresh weight: $\mathrm{P}<0.05$, dry weight: $\mathrm{P}<0.05$ ).

The linear mixed effect model, computed for the growth of the compartments before the harvest revealed that only the E. nuttallii in compartments with increased $\mathrm{PO}_{4}{ }^{3-}$ concentration showed a significant influence of the fertiliser on the growth (time $\mathrm{x}$ fertiliser $\mathrm{P}<0.05$ ). The linear mixed effect model computed after the harvest also showed a highly significant interaction between the development of $E$. nuttallii and the $\mathrm{PO}_{4}{ }^{3-}$ fertiliser (time $\mathrm{x}$ fertiliser $\mathrm{P}<0.05$ ). Neither the $\mathrm{NH}_{4}{ }^{+}$fertilised compartments (before harvest $\mathrm{P}=0.404$, after harvest $\mathrm{P}=0.613$ ) nor the compartments treated with a $\mathrm{NH}_{4}{ }^{+} / \mathrm{PO}_{4}{ }^{3-}$ combination (before harvest $\mathrm{P}=0.199$, after harvest $\mathrm{P}=0.093$ ) showed a similar interaction.

\section{DISCUSSION}

E. nuttallii reproduces mainly vegetatively within $\mathrm{Eu}-$ rope (Barrat-Segretain and Bornette, 2000; Casper and
Krausch, 1980; Simpson, 1984), therefore the regenerative capacity and the survivability of the fragments is crucial for its ability to colonise new areas or to recolonise harvested areas. Although some previous studies have examined the spread of $E$. nuttallii or the effect of management on its populations, for example Barrat-Segretain and Bornette (2000), Barrat-Segretain et al. (2002), Nino et al. (2005) and Hoffmann et al. (2013), none of these studies considered the influence of environmental conditions on the management methods or fragments with less than five initial nodes. Small fragments, however, are still able to regenerate (Casper and Krausch, 1980) and often remain in the lakes after a management campaign. Therefore, the results of the present study can be useful for reducing the consequences of an unintentional spread of small fragments of $E$. nuttallii and improving the efficiency of mechanical management.

The results of the laboratory experiments indicated that lower water temperatures during the cutting and harvesting can increase the management success. The fragments in aquaria with $20^{\circ} \mathrm{C}$ grew significantly faster than the plants in the aquaria with $15^{\circ} \mathrm{C}$, due to the increased cellular activity of the plants (Richter, 1997). A previous study conducted by Kunii (1982) supports this finding. Kunii (1982) showed that $E$. nuttallii plants in water with a temperature of $18^{\circ} \mathrm{C}$ grow about 1.5 times faster than fragments in water with a temperature of $12^{\circ} \mathrm{C}$. The high growth rates under warm water conditions enable $E$. nuttallii to recover lost plant material much faster and there-
Tab. 4. Mean relative growth rates and mortalities at the end of the sediment experiment. Data is shown with standard error of the mean.

\begin{tabular}{|c|c|c|c|}
\hline & $\begin{array}{c}2 \text { nodes } \\
\left(\text { RGR-L d }{ }^{-1}\right)\end{array}$ & $\begin{array}{c}3 \text { nodes } \\
\left(\mathbf{R G R}-\mathrm{L} \mathrm{d}^{-1}\right)\end{array}$ & $\begin{array}{c}4 \text { nodes } \\
\left(\text { RGR-L d }^{-1}\right)\end{array}$ \\
\hline No sediment & $0.010(0.004)^{\mathrm{a}}$ & $0.014(0.004)^{\mathrm{a}}$ & $0.010(0.004)^{\mathrm{a}}$ \\
\hline Sediment 1 & $0.007(0.002)^{\mathrm{a}}$ & $0.013(0.003)^{\mathrm{a}}$ & $0.018(0.001)^{b}$ \\
\hline \multirow[t]{2}{*}{ Sediment 2} & $0.016(0.004)^{\mathrm{b}}$ & $0.022(0.005)^{\mathrm{b}}$ & $0.027(0.003)^{\mathrm{c}}$ \\
\hline & $\begin{array}{c}2 \text { nodes } \\
\left(\operatorname{RGR~d}^{-1}\right)\end{array}$ & $\begin{array}{l}3 \text { nodes } \\
\left(\mathbf{R G R ~ d}^{-1}\right)\end{array}$ & $\begin{array}{c}4 \text { nodes } \\
\left(\mathrm{RGR} \mathrm{d}^{-1}\right)\end{array}$ \\
\hline No sediment & $0.056(0.001)^{\mathrm{a}}$ & $0.085(0.002)^{\mathrm{a}}$ & $0.085(0.002)^{\mathrm{a}}$ \\
\hline Sediment 1 & $0.090(0.002)^{\mathrm{b}}$ & $0.100(0.004)^{\mathrm{b}}$ & $0.116(0.002)^{b}$ \\
\hline \multirow[t]{2}{*}{ Sediment 2} & $0.105(0.004)^{\mathrm{c}}$ & $0.119(0.004)^{c}$ & $0.124(0.008)^{\mathrm{c}}$ \\
\hline & $\begin{array}{c}2 \text { nodes } \\
\text { Mortality (\%) }\end{array}$ & $\begin{array}{c}3 \text { nodes } \\
\text { Mortality (\%) }\end{array}$ & $\begin{array}{c}4 \text { nodes } \\
\text { Mortality (\%) }\end{array}$ \\
\hline No sediment & 25 & 25 & 25 \\
\hline Sediment 1 & 12.5 & 0 & 0 \\
\hline Sediment 2 & 12.5 & 0 & 0 \\
\hline
\end{tabular}

$\overline{R G R-L \text {, relative longitudinal growth rate; } R G R \text {, relative biomass growth }}$ rate. ${ }^{a, b, c}$ Different superscripts in the same column indicate significant differences $(P<0.05)$.
Tab. 5. Relative growth rates, fresh weight and dry weight per compartment at the harvest and at the end of the fertilisation experiment. Data is shown with standard error of the mean.

\begin{tabular}{lcc}
\hline Fertiliser & $\begin{array}{c}\text { Harvest } \\
\left(\text { RGR-L d }{ }^{-1}\right)\end{array}$ & $\begin{array}{c}\text { End } \\
(\text { RGR-L d }\end{array}$ \\
\hline Control & $0.074(0.002)^{\mathrm{aA}}$ & $0.050(0.001)^{\mathrm{aB}}$ \\
$\mathrm{N}$ & $0.078(0.005)^{\mathrm{aA}}$ & $0.050(0.009)^{\mathrm{aB}}$ \\
$\mathrm{P}$ & $0.063(0.004)^{\mathrm{bA}}$ & $0.074(0.004)^{\mathrm{bB}}$ \\
$\mathrm{N}+\mathrm{P}$ & $0.078(0.003)^{\mathrm{aA}}$ & $0.039(0.003)^{\mathrm{cB}}$ \\
\hline & Fresh weight harvest $(\mathrm{g})$ & Fresh weight end $(\mathrm{g})$ \\
\hline Control & $54.81(1.85)^{\mathrm{a}}$ & $36.92(9.7)^{\mathrm{a}}$ \\
$\mathrm{N}$ & $62.79(10.6)^{\mathrm{b}}$ & $38.87(10.2)^{\mathrm{a}}$ \\
$\mathrm{P}$ & $44.25(8.6)^{\mathrm{c}}$ & $68.52(9.8)^{\mathrm{b}}$ \\
$\mathrm{N}+\mathrm{P}$ & $82.34(10.5)^{\mathrm{b}}$ & $20.32(1.8)^{\mathrm{c}}$ \\
\hline & Dry weight harvest $(\mathrm{g})$ & Dry weight end $(\mathrm{g})$ \\
\hline Control & $2.53(0.4)^{\mathrm{a}}$ & $2.91(0.7)^{\mathrm{a}}$ \\
$\mathrm{N}$ & $3.62(0.6)^{\mathrm{b}}$ & $2.96(07)^{\mathrm{a}}$ \\
$\mathrm{P}$ & $2.44(0.4)^{\mathrm{a}}$ & $5.06(0.8)^{\mathrm{b}}$ \\
$\mathrm{N}+\mathrm{P}$ & $4.22(0.8)^{\mathrm{b}}$ & $1.83(0.5)^{\mathrm{c}}$ \\
\hline$R G R-L$ & &
\end{tabular}

$R G R-L$, relative longitudinal growth rate; $\mathrm{N}, \mathrm{NH}_{4}^{+}$-fertiliser; $\mathrm{P}_{2} \mathrm{PO}_{4}{ }^{3-}$ fertiliser. ${ }^{a, b, c}$ Different superscripts in the same column indicate significant differences $(P<0.05) ;{ }^{A, B}$ different superscripts in the same row indicate significant differences $(P<0.05)$. 
fore decrease the efficiency of the management compared to fragments in colder water. The present study showed that in warm waters only fragments with one or two nodes show an increased mortality and larger fragments is not affected. Taking into account the higher growth rates in warm water, it can be assumed that the effect of the increased mortality might be countered or even exceeded by the higher growth of the fragments. Therefore, the management of E. nuttallii has to be considered as less successful under warm water conditions and as a consequence of this E. nuttallii should be cut and harvested during a period with low water temperatures, for example early spring or late autumn, to increase the efficiency of the method. Similarly, also the findings of the light experiment support this conclusion. Overall, the experiment showed that the regenerative capacity and the survivability of $E$. nuttallii fragments is reduced during periods with low global irradiance $\left(<86 \mu \mathrm{mol}\right.$ photons $\left.\mathrm{m}^{-2} \mathrm{~s}^{-1}\right)$. Al- though the growth rate of the small fragments (one or two nodes) increased at light intensities below $86 \mu \mathrm{mol}$ photons $\mathrm{m}^{-2} \mathrm{~s}^{-1}$, the growth rates of the larger fragments, as well as the overall survivability decreased considerably. This is in agreement with previous studies that showed how low light conditions decrease the growth rates of large E. nuttallii fragments (Kunii, 1984a; Cook and Urmi-König, 1985). Angelstein and Schubert (2009) reported, in addition to this that rooted $E$. nuttallii developed considerably lower growth rates at light intensities below $51 \mu \mathrm{mol}$ photons $\mathrm{m}^{-2} \mathrm{~s}^{-1}$.

The light conditions in lakes are affected by different parameters. The global irradiance depends on the cloud cover and more important the zenith angle of the sun. At a low angle, for example during spring or autumn, the light intensity is significantly reduced (Gege, 2012). The light attenuation of the water on the other hand is affected by the optical properties of the water, more precisely tur-
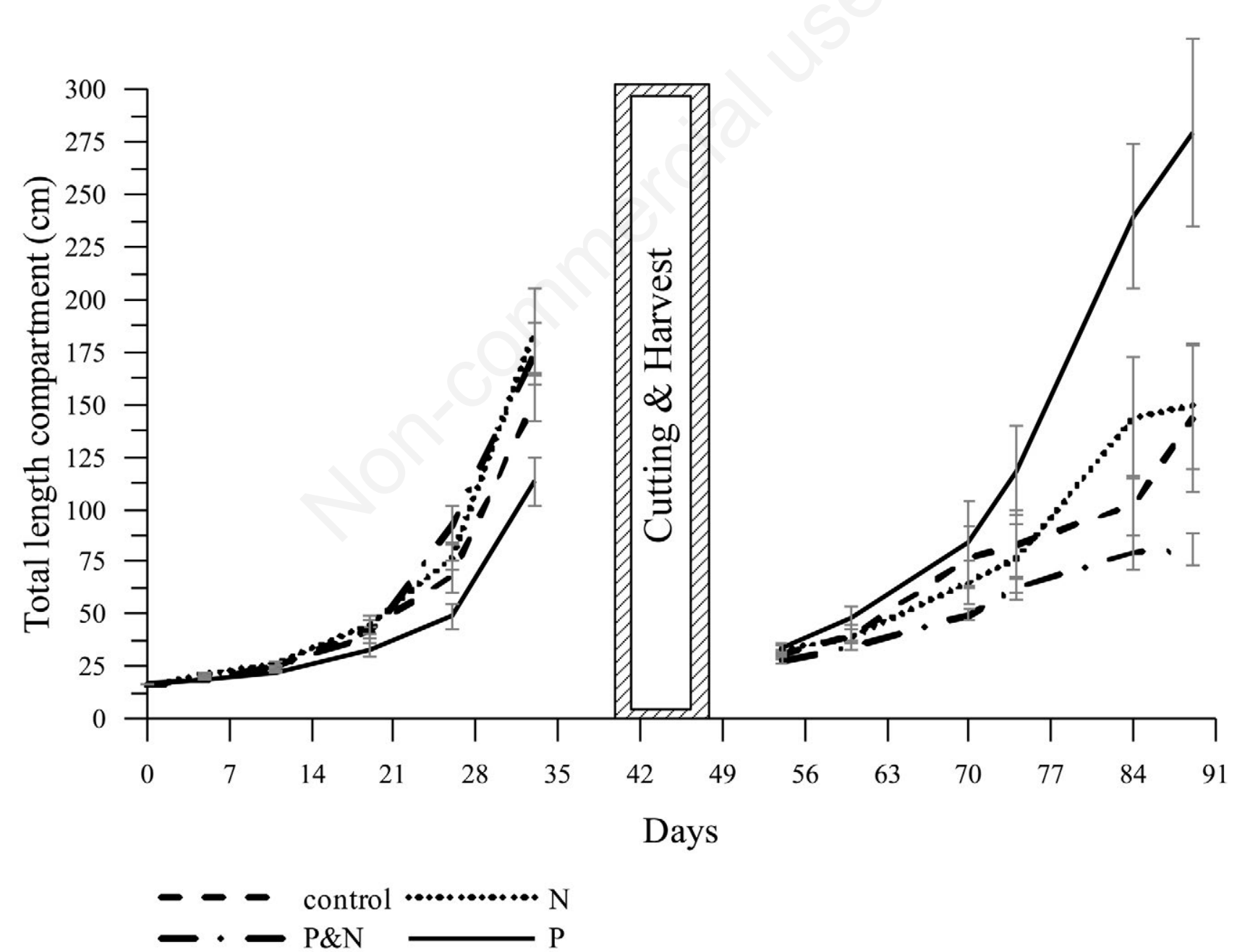

Fig. 2. Mean total lengths in the compartments during the fertilisation experiment in Lake Starnberg. Data is shown with standard error of the mean (SEM). N, treated with $\mathrm{NH}_{4}{ }^{+}$- fertiliser; $\mathrm{P}$, treated with $\mathrm{PO}_{4}{ }^{3-}$ fertiliser; $\mathrm{P} \& \mathrm{~N}$, treated with $\mathrm{NH}_{4}{ }^{+}$and $\mathrm{PO}_{4}{ }^{3-}$ fertiliser. 
bidity (Lee et al., 1999). Shallow lakes in the temperate zone shift regularly between turbid and clear-water states during the year: The lakes are in a turbid state during spring and autumn, because of the dominance of phytoplankton. During summer macrophytes dominate the lakes and as a result the lakes shift to a clear-water state (Schwoerbel and Brendelberger, 2005). Consequently, the cutting and harvesting of $E$. nuttallii should be most successful during the cold water period in spring and autumn, because of the low zenith angle of the sun and the natural occurrence of turbidity.

Although the cutting and harvesting of E. nuttallii during spring and autumn seems less effective than a management during summer, when the plant biomass reaches its maximum, an early, respectively late, management has various advantages, apart from the low temperature and light intensity. Cutting and harvesting $E$. nuttallii during spring, for example, favours slow growing, native macrophytes by suppressing the extensive growth of $E$. nuttallii plants. A management during autumn, on the other hand, reduces the amount of fragments during winter and therefore affects the spread of $E$. nuttallii plants during the next vegetation period. Due to the vegetative reproduction behaviour of E. nuttallii, a sufficient amount of E. nuttallii fragments has to survive the winter to enable the recolonisation of the lake (Casper and Krausch, 1980; Kunii, 1981; Kunii, 1984b). Therefore, a reduction of the fragments in the lakes before/during winter also affects the ability of E. nuttallii to recolonise the lake in the following year.

The results of the sediment experiment in the laboratory and the field indicate that the efficiency of cutting and harvesting in lakes depends on the nutrient concentration in the sediment. Although, E. nuttallii prefers to absorb nutrients through the shoots (Eugelink, 1998; Angelstein and Schubert, 2008), the laboratory experiment revealed that the absence of sediment (or extremely nutrient poor sediment) can decrease the survivability and growth of $E$. nuttallii fragments, if the water is rather nutrient poor. Similar findings were reported in previous studies, which examined the influence of nutrients on the growth of large fragments or rooted E. nuttallii, e.g. Best et al. (1996), Eugelink (1998), Özbay (2001) Angelstein et al. (2009). Furthermore, the field experiment and studies by Best et al. (1996) and Özbay (2001) showed that, apart from the amount, the composition of nutrients, more precisely the phosphorus-nitrate ratio in the sediment, has a significant influence on the growth and regenerative capacity of E. nuttallii. Although phosphorus is the limiting factor in aquatic ecosystems (Schwoerbel and Brendelberger, 2005), the results of the studies indicated that high $\mathrm{PO}_{4}{ }^{3-}$ concentration in the sediment inhibit the growth of established E. nuttallii plants. On the other hand, Rolland and Tremolieres (1995) and Nagasaka (2004) showed that a slow but continuous addition of $\mathrm{PO}_{4}^{3-}$ or higher concentrations of $\mathrm{NH}^{+}$increase the growth of established E. nuttallii plants. In addition to these findings, the present study revealed that an increased $\mathrm{PO}_{4}{ }^{3-}$ concentration in the sediment can significantly increase the growth (regenerative capacity) of E. nuttallii fragment after a harvest. Kunii (1981) and Barrat-Segretain et al. (1999) indicated that the different growth rates before and after the harvest are the result of differences in the development of whole plants and plant fragments. Consequently, an analysis of the lake sediment, more precisely the nutrient concentration and composition, can be used to improve the management of E. nuttallii. Depending on the nutrient concentration and composition, the frequency and intensity of the management can be adjusted to counter the increased growth and/or regenerative capacity of the plants. Additionally, the cutting and harvesting of the plants could be combined with different management methods, for example benthic barriers (Hoffmann et al., 2013), to increase the efficiency and success of the management.

\section{CONCLUSIONS}

The present study proved that water temperatures, light intensity, as well as the sediment conditions affect the growth, regenerative capacity and survivability of $E$. nuttallii fragments. As a consequence, also the efficiency of mechanical management methods is profoundly affected by environmental conditions. Accordingly, the present results can be used to improve the mechanical management. However, each experiment focused only on one environmental condition, therefore additional research regarding the interactions between different environmental conditions might reveal further parameters or combinations of parameters which affect the regenerative capacity and survivability of $E$. nuttallii fragments.

\section{ACKNOWLEDGMENTS}

The study is part of the Bavarian Research Cooperation FORKAST: Impact of climate on aquatic ecosystems and climatic adaption strategies, funded by the Bavarian State Ministry of Science, Research and the Arts and by the Bavarian State Ministry of the Environment and Public Health. A special thanks to Pauline Hein and Alberto Benavent González who helped with the preparation and realisation of the experimental setups, as well as the data collection during the study.

\section{REFERENCES}

Angelstein S, Schubert H, 2008. Elodea nuttallii: uptake, translocation and release of phosphorus. Aquat. Biol. 3:209-216.

Angelstein S, Schubert H, 2009. Light acclimatisation of Elodea nuttallii grown under ambient DIC conditions. Plant Ecol. 202:91-101. 
Angelstein S, Wolfram C, Rahn K, Kiwel U, Frimel S, Merbach I, Schubert H, 2009. The influence of different sediment nutrient contents on growth and competition of Elodea nuttallii and Myriophyllum spicatum in nutrient-poor waters. Fund. Appl. Limnol. 175:49-57.

Barrat-Segretain MH, 2001. Invasive species in the Rhone River floodplain (France): replacement of Elodea canadensis Michaux by E. nuttalli St. John in two former river channels. Arch. Hydrobiol. 152:237-251.

Barrat-Segretain MH, 2005. Competition between invasive and indigenous species: impact of spatial pattern and developmental stage. Plant Ecol. 180:153-160.

Barrat-Segretain MH, Bornette G, 2000. Regeneration and colonization abilities of aquatic plant fragments: effect of disturbance seasonality. Hydrobiologia 421:31-39.

Barrat-Segretain MH, Elger A, Sagnes P, Puijalon S, 2002. Comparison of three life-history traits of invasive Elodea canadensis Michx. and Elodea nuttallii (Planch.) H. St. John. Aquat. Bot. 74: 99-313.

Barrat-Segretain MH, Henry CP, Bornette G, 1999. Regeneration and colonization of aquatic plant fragments in relation to the disturbance frequency of their habitats. Arch. Hydrobiol. 145:111-127.

Best EPH, Woltman H, Jacobs FHH, 1996. Sediment-related growth limitation of Elodea nuttallii as indicated by fertilization experiment. Freshwater Biol. 36:33-44.

Casper SJ, Krausch HD, 1980. [Pteridophyta und Anthophyta].[Book in German]. Spektrum: 530 pp.

Cook CDK, Urmi-König K, 1985. A revision of the genus Elodea (Hydrocharitaceae). Aquat. Bot. 21:111-156.

Erhard D, Gross EM, 2006. Allelopathic activity of Elodea canadensis and Elodea nuttallii against epiphytes and phytoplankton. Aquat. Bot. 85:203-211.

Erhard D, Pohnert G, Gross EM, 2007. Chemical Defense in Elodea nuttallii reduces feeding and growth of aquatic herbivorous Lepidoptera. J. Chem. Ecol. 33:1646-1661.

Eugelink AH, 1998. Phosphorus uptake and active growth of Elodea canadensis Michx. and Elodea nuttallii (planch.) St. John. Water Sci. Technol. 37: 59-65.

Gege P, 2012. Analytic model for the direct and diffuse components of downwelling spectral irradiance in water. OSA Proc. 51:1407-1419.

Herault B, Bornet A, Tremolieres M, 2008. Redundancy and niche differentiation mong the European invasive Elodea species. Biol. Invasions 10:1099-1107.

Hoffmann M, González AB, Raeder U, Melzer A, 2013. Experimental weed control of Najas marina ssp. intermedia and Elodea nuttallii in lakes using biodegradable jute matting. J. Limnol. 72:485-493.

Hussner A, 2012. Alien aquatic plant species in European countries. Weed Res. 52:297-306.

Hussner A, Van de Weyer K, Gross EM, Hilt S, 2010. Comments on increasing number and abundance of non-indigenous aquatic macrophyte species in Germany. Weed Res. 50:519-526.

Jones JI, Eaton JW, Hardwick K, 2000. The effect of changing enviromental variables in the surrounding water on the physiology of Elodea nuttallii. Aquat. Bot. 66:115-129.

Kelly DJ, Hawes I, 2005. Effects of invasive macrophytes on littoral-zone productivity and foodweb dynamics in a New Zealand high-country lake. J. N. Am. Benthol. Soc. 25:300-320.
Kowarik I, 2003.[Biologische Invasionen: Neophyten und Neozoen in Mitteleuropa].[Book in German]. Eugen Ulmer GmbH: 320 pp.

Kunii H, 1981. Characteristics of the winter growth of detached Elodea nuttallii (Planch.) St. John in Japan. Aquat. Bot. 11:57-66.

Kunii H, 1982. The critical water temperature for the active growth of Elodea nuttallii. Jap. J. Ecol. 32:111-112.

Kunii H, 1984a. Effect of light intensity on the growth and buoyancy of detached Elodea nuttallii (Planch.) St. John during the winter. Bot. Mag. Tokyo 97:287-295.

Kunii H, 1984b. Seasonal growth and profile structure development of Elodea nuttallii (Planch.) St. John in pond Ojagaike, Japan. Aquat. Bot. 18:239-248.

Lee ZP, Carder KL, Mobley CD, Steward RG, Patch JF, 1999. Hyperspectral remote sensing for shallow waters: II. Deriving bottom depths and water properties by optimization. Appl. Optic. 38:3831-3843.

Mazej Z, Jelenko I, Germ M, 2014. Influence of abiotic factors on invasive behaviour of alien species Elodea nuttallii in the Drava River (Slovenia). Ann. Limnol. 50:1-8.

Nagasaka M, 2004. Changes in biomass and spatial distribution of Elodea nuttallii (Planch.) St. John, an invasive submerged plant, in oligomesotrophic Lake Kizaki from 1999 to 2002. Limnology 5:129-139.

Nino D, Thiébaut G, Muller S, 2005. Response of Elodea nuttallii (Planch.) H. St. John to manual harvesting in the North-East of France. Hydrobiologia 551:147-157.

Özbay H, 2001. Testing growth of Elodea nuttallii (Planch.) St. John with different culture media. Turk. J. Bot. 239-244.

Pieterse AH, Murphy KJ, 1990. Aquatic weeds: the ecology and management of nuisance aquatic vegetation. Oxford University Press: 593 pp.

Podraza P, Brinkmann T, Evers P, von Felde D, Forst U, Klopp R, Knotte H, Kühlmann M, Kuk M, Lipka P, Nusch EA, Stengert M, Wessel M, van de Weyer K, 2008. [Untersuchungen zur Massenentwicklung von Wasserpflanzen in den Ruhrstauseen und Gegenmaßnahmen]. [Report in German]. Ministerium für Umwelt und Naturschutz, Landwirtschaft und Verbraucherschutz des Landes NRW, Düsseldorf, Germany. Available from: http://www.ruhrverband.de/fileadmin/pdf/elodea_abschlussbericht.pdf

Richter G, 1997. [Stoffwechselphysiologie der Pflanzenphysiologie und Biochemie des Primär- und Sekundärstoffwechsels].[Book in German]. Thieme: 592 pp.

Rolland T, Tremolieres M, 1995. The role of ammonium nitrogen in the distribution of two species of Elodea. Acta Bot. Gallica 142:733-739

Schwoerbel J, Brendelberger H, 2005. [Einführung in die Limnologie, 9].[Book in German]. Spektrum: 340 pp.

Simpson DA, 1984. A short history of the introduction and spread of Elodea Michx in the British Isles. Watsonia 15:1-9.

Simpson DA, 1990. Displacement of Elodea canadensis Michx by Elodea nuttallii (Planch.) H. St John in the British Isles. Watsonia 18:173-177.

Tremp H, 2001. [Standörtliche Differenzierung der Vorkommen von Elodea canadensis Michx. und Elodea nuttallii (Planch.) St. John in Gewässern der badischen Oberrheinebene].[Article in German]. Ber. Inst. LandschaftsPflanzenökologie Univ. Hohenheim 10:19-32. 